\title{
Patient outcome in the year following severe head injury and relatives' psychiatric and social functioning
}

\author{
MARTIN G LIVINGSTON, D NEIL BROOKS, MICHAEL R BOND \\ From the Department of Psychological Medicine, University of Glasgow, Glasgow, UK
}

SUMMARY Fifty-seven consecutive severe male head injury patients together with a defined female relative were assessed at home 3,6 and 12 months after injury in order to measure the psychiatric and social impact of the injury on the relative. Relatives were found to have significant and persistent psychiatric and social dysfunction and they considered themselves to have a high burden in caring for the relative throughout the year. No particular relationship was found to be the more vulnerable. The most frequent predictor of the relatives' psychiatric and social status was the level of symptomatic complaints voiced by the patients. The findings suggest the need for comprehensive rehabilitation of head injury patients and their relatives.

After a severe head injury, there is often a critical period when survival is the main issue. ${ }^{1}$ Those who subsequently return home frequently present a multitude of deficits and handicaps. ${ }^{2-5}$ Often the main burden in dealng with these problems falls on the shoulders of a close relative, usually female.

Rosenbaum and Najenson ${ }^{6}$ assessed a group of Israeli war wounded soldiers and their wives 1 year after injury. They used two control groups of relatives. Higher levels of depression were recorded in the head injury wives, associated with behavioural and role shifts in their husbands.

A mixed sex group of relatives of 54 head injured patients was studied prospectively at 1 month, 6 months and 12 months after injury by Odddy et al. ${ }^{7}$ They too found high levels of depression (Wakefield Depression Inventory) in the relatives, particularly at 1 month after injury when $39 \%$ scored above the threshold level on the scale. This reduced to approximately $20 \%$ at the later follow-ups, although the incidence of "emotional or psychosomatic" disorders remained high throughout the year. This latter figure is however consistent with the incidence of minor emotional disorder in a normal population. ${ }^{8}$ The high levels of depression were found to be associated with the duration of post traumatic amnesia (PTA), ${ }^{9}$ the time spent in hospital and with

Address for reprint requests: Dr MG Livingston, Dept of Psychological Medicine, University of Glasgow, 6 Whittingehame Gardens, Great Western Rd, Glasgow G12 0AA, UK.

Received 9 November 1984 and in revised form 29 January 1985. Accepted 26 February 1985 return to work. They were, in addition, associate $\phi_{\infty} \infty$ with personality change and subjective complaints i $i \overline{\text { के }}$ the patients.

McKinlay et al ${ }^{10}$ studied a close relative of $5 \Phi^{+} \rightarrow$ severely head injured adults (PTA greater than of $\mathbb{D}$ equal to 2 days). Relatives were asked at 3,6 and 12 months after injury to rate stress experienced on $\$$ seven point scale. Over $70 \%$ scored either medium or high stress on each occasion, associated with mene tal and behavioural changes in the patient. Workers from the same group ${ }^{1}$ examined the relationship between strain in relatives (a measure of subjective burden) and personality change in the patient in more detail. As the year after the injury progressed, an increased association developed between personality change in patients and subjective burden in the relatives.

The studies quoted provide some replicable assessment of patient and relative functioning following head injury, but interpretation of the results is not always easy. The Israeli study ${ }^{6}$ used a very small sample and their staff control group may not be helpful. Oddy et al's sample ${ }^{7}$ was skewed towards the young (aged 16-39 years) and upper social classes, and therefore really included good prognosis groups only. All the studies mentioned assess essentially one aspect of relatives' psychosocial functioning using either a mood rating or a "stress" rating, but the results are nevertheless reasonably consistent. Relatives are subject to distress over at least 1 을. year following injury. This seems to be associated $N$ more with day-to-day symptomatic complaints rather than with the initial severity of the injury. In 
Table 1 Patients social class

\begin{tabular}{lccc}
\hline Social class & $\begin{array}{c}3 \text { months } \\
n=42\end{array}$ & $\begin{array}{l}6 \text { months } \\
n=47\end{array}$ & $\begin{array}{l}12 \text { months } \\
n=50\end{array}$ \\
\hline I & 1 & 1 & 1 \\
II & 2 & 2 & 2 \\
III & 24 & 25 & 26 \\
IV & 5 & 9 & 10 \\
V & 10 & 10 & 11 \\
\hline
\end{tabular}

particular personality and behavioural change are less well tolerated.

More detailed knowledge about the psychiatric and social adjustment of relatives of the head injured and its association with patients' functioning would have implications for designing rehabilitation programmes involving patients and families. None of the studies available at present includes anything more than a rudimentary assessment of the patients' functioning, for example relatives are often asked to rate the patient's outcome. Whilst this is a valid approach, ${ }^{11}$ it clearly has limitations. Relatives may, in fact, simply report on areas problematic for themselves. In view of these limitations, this study was set up to examine both patients and relatives at home throughout the year following a severe head injury.

\section{Method}

\section{Aims}

The study was designed to answer the following questions about the relatives of severe head injury victims who survived to return to the family home: (1) Does the relative's psychiatric functioning alter throughout the year? (2) Does the relative's social functioning alter throughout the year? (3) Is there a different psychiatric and social outcome for wives and mothers? (4) What features in the patients are predictive of psychiatric and social functioning in the relatives?

\section{Population}

Patients and relatives were defined as in a previous study. ${ }^{12}$ Both were seen in the family home by one of the authors (MGL), at 3, 6 and 12 months following injury. Fifty-seven patients and their relative were included, 37 of them assessed on three occasions. Forty-two patients and relatives were seen at 3 months, 47 at 6 months and 50 at 1 year

Table 2 Patients ages, by decades, in each group

\begin{tabular}{llll}
\hline $\begin{array}{l}\text { Patients ages } \\
\text { (Years) }\end{array}$ & $\begin{array}{l}\text { Percent } \\
3 \text { months } \\
n=42\end{array}$ & $\begin{array}{l}\text { Percent } \\
6 \text { months } \\
n=47\end{array}$ & $\begin{array}{l}\text { Percent } \\
12 \text { months } \\
n=50\end{array}$ \\
\hline $16-19$ & 24 & 23 & 24 \\
$20-29$ & 16 & 15 & 16 \\
$30-39$ & 16 & 21 & 22 \\
$40-49$ & 14 & 13 & 10 \\
$50-59$ & 19 & 17 & 18 \\
$60-64$ & 11 & 11 & 10 \\
\hline
\end{tabular}

Table 3 PTA of patients in each group

\begin{tabular}{lccc}
\hline PTA & $\begin{array}{l}\text { Percent } \\
3 \text { months } \\
n=42\end{array}$ & $\begin{array}{l}\text { Percent } \\
6 \text { months } \\
n=47\end{array}$ & $\begin{array}{l}\text { Percent } \\
12 \text { months } \\
n=50\end{array}$ \\
\hline Less than 2 days & 0 & 0 & 0 \\
2-6 days & 21 & 21 & 18 \\
$7-27$ days & 38 & 34 & 38 \\
28-83 days & 33 & 34 & 32 \\
$\begin{array}{l}\text { Greater than } 83 \\
\text { days }\end{array}$ & 7 & 11 & 12 \\
\hline
\end{tabular}

following injury. The difference in numbers was due to some patients being too ill to return home by 3 months and by the inclusion at 6 and 12 months of people seen in a pilot study. The pilot study was set up to examine the feasibility of the methodology. This was found to be satisfactory. Primarily because of follow-up at home, only one patient defaulted at the 1 year follow-up. Patients and relatives, additional to the 37 with completed follow-up, will only be considered when making comparisons between 3 and 6 months assessments and 6 and 12 months assessments.

\section{Demography}

Table 1 shows the social class distribution of the total sample based on the occupation of the male "head of household'. There is a marked preponderance towards the lower socio-economic groups. Table 2 shows patients' ages grouped in decades for the total sample. At least $50 \%$ of the patients were aged less than 39 years. Table 3 illustrates PTA (assessed retrospectively) for the patients. Over $75 \%$ of the patients had PTA for longer than 2 days and $40 \%$ for longer than 1 month, indicating the marked severity of injury in this group.

Comparison of patients' ages in the sample seen at 3 and 6 months, and again in the sample seen at 6 and 12 months, revealed no statistically significant differences ( 2 tailed paired $t$ test) and similar comparisons held true for relative's ages. The social class breakdown of the relatives was remarkably similar to that of the patients. About $6 \%$ were in social class I or II, $50 \%$ in social class III and approximately $20 \%$ in each of social classes IV and V.

\section{Measures}

The measures used were the same as those employed in a previous study comparing minor head injury patients and relatives with severe head injury patients and relatives. ${ }^{12}$

\section{Results}

\section{Does the psychiatric functioning of the relatives} alter throughout the year?

The relatives' scores on the General Health Questionnaire and Leeds scales throughout the year are shown in table 4. These show high scores on the GHQ and Leeds Anxiety scale which persist throughout the year. In fact the mean score on the GHQ at 6 months $(12.64$, SD 14.89$)$ is above the caseness threshold as are the Leeds Anxiety scores throughout the year. When 3 and 6 month scores are 
Table 4 Comparison of relatives scores, at each time of testing, on psychiatric rating scales

\begin{tabular}{|c|c|c|c|c|c|}
\hline Variable & $N$ & Mean & $S D$ & (Paired) $t$ & $\begin{array}{l}\text { 2-tail } \\
\text { probability }\end{array}$ \\
\hline $\begin{array}{l}G H Q \\
3 \text { months } \\
6 \text { months }\end{array}$ & 36 & $\begin{array}{r}9 \cdot 89 \\
13 \cdot 37\end{array}$ & $\begin{array}{l}10 \cdot 95 \\
15 \cdot 43\end{array}$ & $1 \cdot 37$ & $0 \cdot 18$ \\
\hline $\begin{array}{r}6 \text { months } \\
12 \text { months }\end{array}$ & 42 & $\begin{array}{l}13 \cdot 36 \\
11 \cdot 19\end{array}$ & $\begin{array}{l}15.44 \\
15 \cdot 44\end{array}$ & 0.94 & 0.35 \\
\hline $\begin{array}{r}\text { Leeds anxiety } \\
3 \text { months } \\
6 \text { months }\end{array}$ & 37 & $\begin{array}{l}7.65 \\
7 \cdot 79\end{array}$ & $\begin{array}{l}4 \cdot 67 \\
4 \cdot 58\end{array}$ & $0 \cdot 26$ & 0.80 \\
\hline $\begin{array}{r}6 \text { months } \\
12 \text { months }\end{array}$ & 42 & $\begin{array}{l}7 \cdot 84 \\
7 \cdot 95\end{array}$ & $\begin{array}{l}5 \cdot 57 \\
5 \cdot 56\end{array}$ & $0 \cdot 23$ & 0.82 \\
\hline $\begin{array}{l}\text { Leeds depressi } \\
3 \text { months } \\
6 \text { months }\end{array}$ & 37 & $\begin{array}{l}4 \cdot 81 \\
4 \cdot 51\end{array}$ & $\begin{array}{l}4 \cdot 03 \\
3 \cdot 72\end{array}$ & $0 \cdot 60$ & 0.55 \\
\hline $\begin{array}{l}6 \text { months } \\
12 \text { months }\end{array}$ & 42 & $\begin{array}{l}4 \cdot 57 \\
4 \cdot 62\end{array}$ & $\begin{array}{l}4 \cdot 09 \\
4 \cdot 43\end{array}$ & 0.07 & 0.94 \\
\hline
\end{tabular}

Table 5 Comparison of numbers of relatives who reach case level on $G H Q$ and Leeds scales at each time of testing

\begin{tabular}{llllll}
\hline Variable & $\begin{array}{l}\text { Non- } \\
\text { cases }\end{array}$ & Cases & $N$ & $\begin{array}{l}\text { Cochran } \\
Q\end{array}$ & Probability \\
\hline GHQ & & & & & \\
$\quad 3$ months & 21 & 14 & 35 & 1.3 & 0.52 \\
6 months & 22 & 13 & & & \\
12 months & 25 & 10 & & & \\
Leeds anxiety & & & & & \\
3 months & 21 & 11 & 32 & 0.5 & 0.78 \\
6 months & 19 & 13 & & & \\
12 months & 20 & 12 & & & \\
Leeds depression & & & & & \\
3 months & 28 & 7 & 35 & 0.6 & 0.74 \\
6 months & 27 & 8 & & & \\
12 months & 26 & 9 & & & \\
\hline
\end{tabular}

compared and 6 and 12 month scores, (paired $t$ tests, 2 tailed), no statistically significant differences are obtained.

Table 5 shows the number of relatives in the caseness range on the measures employed. The figures for the GHQ are 40,37 and $28 \%$ cases at 3,6 and 12 months assessments and for the Leeds Anxiety scales 34,37 and $37 \%$ respectively at the same times of assessment. No statistically significant differences were found. (Cochran's $Q$ test). When relatives are asked to rate their perception of the patient's prob-

Table 6 Relatives perception of burden imposed by patients throughout the year

\begin{tabular}{llll}
\hline Variable & $\begin{array}{l}3 \text { months } \\
\text { mean }(S D) \\
n=42\end{array}$ & $\begin{array}{l}6 \text { months } \\
\text { mean }(S D) \\
n=47\end{array}$ & $\begin{array}{l}12 \text { months } \\
\text { mean }(S D) \\
n=50\end{array}$ \\
\hline $\begin{array}{l}\text { Perceived } \\
\text { burden }\end{array}$ & $7.24(4.91)$ & $7.87(5.73)$ & $7.88(6.13)$ \\
\hline
\end{tabular}

lems (perceived burden) high scores of, on average, more than eight items recorded positive out of a possible 25 are found (table 6 ). Simple inspection of this data shows once again highly consistent responses, that is high burden perceived throughout the year. When paired 2 tailed $t$ testing was carried out, this impression was confirmed, none of the dif ferences being statistically significant.

2 Does the relatives' social functioning alter over the year?

The Global Social Adjustment scores on Weiss man's SAS-SR are shown at each time of testing (table 7). The scores at 6 and 12 months are higher indicating poorer adjustment than at 3 months. The difference between 3 and 6 months scores is statistically significant $(t=2.21, \mathrm{p}<0.03)$ but not between 6 and 12 months scores $(t=0 \cdot 10, p<0.92)$.

The mean role scores for work functioning, social and leisure, extended family functioning, marital role, parental and nuclear family functioning were generally above those recorded by Weissman ${ }^{13}$ in her community survey (see table 8 ). High scores indicate poorer functioning within that role.

When the evolution of the head injured relatives' scores over the year is examined by comparing

Table 7 Comparison of global social adjustment at each time of testing

\begin{tabular}{|c|c|c|c|c|c|}
\hline Variable & $N$ & Mean & $S D$ & $t^{\text {(Paired) }}$ & Probability \\
\hline \multicolumn{6}{|c|}{ Social adjustment scale } \\
\hline $\begin{array}{l}3 \text { months } \\
6 \text { months }\end{array}$ & 38 & $\begin{array}{l}1.65 \\
1.75\end{array}$ & $\begin{array}{l}0.35 \\
0.43\end{array}$ & $2 \cdot 21$ & 0.03 \\
\hline $\begin{array}{l}6 \text { months } \\
12 \text { months }\end{array}$ & 44 & $\begin{array}{l}1.76 \\
1.74\end{array}$ & $\begin{array}{l}0.42 \\
0.51\end{array}$ & $0 \cdot 10$ & 0.92 \\
\hline
\end{tabular}


Table 8 Functioning of relatives in different social roles throughout the year

\begin{tabular}{|c|c|c|c|c|}
\hline & $\begin{array}{l}3 \text { months mean }(S D) \\
n=42\end{array}$ & $\begin{array}{l}6 \text { months mean }(S D) \\
n=47\end{array}$ & $\begin{array}{l}12 \text { months mean }(S D) \\
n=50\end{array}$ & $\begin{array}{l}\text { Weissman's Community Sample } \\
\text { mean }(S D) n=482\end{array}$ \\
\hline Work functioning & $1.44(0.39)$ & $1.54(0.55)$ & $1.48(0.53)$ & $1.40(0.46)$ \\
\hline functioning & $1.97(0.47)$ & $2.06(0.58)$ & $2.09(0.64)$ & $1.83(0.52)$ \\
\hline $\begin{array}{l}\text { extended family } \\
\text { Functioning in the nuclear }\end{array}$ & $1.39(0.33)$ & $1.34(0.30)$ & $1.42(0.48)$ & $1.34(0.33)$ \\
\hline $\begin{array}{l}\text { family } \\
\text { Marital functioning } \\
\text { Parental functioning } \\
\text { Economic functioning }\end{array}$ & $\begin{array}{l}1.74(0.73) \\
1.95 \\
1.37(0.47) \\
1.70(0.48)\end{array}$ & $\begin{array}{l}1.81(0.72) \\
2.13(0.62) \\
1.52(0.55) \\
1.64(0.99)\end{array}$ & $\begin{array}{l}1.76(0.67) \\
2 \cdot 10(0.69) \\
1.49(0.52) \\
1.66(1.02)\end{array}$ & $\begin{array}{l}1.46(0.58) \\
1.75(0.48) \\
1.40(0.42) \\
\text { Not available }\end{array}$ \\
\hline
\end{tabular}

scores at 3 and 6 months and at 6 and 12 months ( 2 tailed paired $t$ test), statistically significant differences were recorded between 3 and 6 months' scores on marital functioning $(t=2 \cdot 66, \mathrm{p}<0.01)$. The results demonstrate the gradual development of social maladjustment between 3 and 6 months but a fair degree of consistency in the individual role scores over the year. The scores recorded were on average poorer than a US community sample with differences most evident in marital functioning.

3 Is there a different psychiatric and social outcome for wives and mothers of severe head injury victims? At the 3 month assessment there were 22 wives and 16 mothers, at 6 months 25 wives and 17 mothers, and at 12 months 25 wives and 20 mothers. Wives' and mothers' scores on the GHQ, the Leeds scales for anxiety and depression, Social Adjustment Schedule and perceived burden rating were compared at 3 and 6 and 6 and 12 months ( 2 tailed independent sample $t$ tests). No statistically significant differences were recorded either in terms of psychiatric symptomatology, caseness or global social adjustment.

Table 9 shows perceived burden ratings for each group of relatives throughout the year. There seems to be a clear trend of wives perceived burden becoming more apparent at 6 months and persisting to the 12 months stage. The mothers show modest improvement in perceived burden. However when comparing mothers with wives at 3,6 and 12 months

Table 9 Perceived burden: wives compared with mothers at three and six months and six and twelve months after injury

\begin{tabular}{llll}
\hline $\begin{array}{l}\text { Perceived } \\
\text { burden }\end{array}$ & $\begin{array}{l}3 \text { months } \\
\text { mean }(S D) \\
n=38\end{array}$ & $\begin{array}{l}6 \text { months } \\
\text { mean }(S D) \\
n=43\end{array}$ & $\begin{array}{l}12 \text { months } \\
\text { mean }(S D) \\
n=47\end{array}$ \\
\hline Wives & $6.55(4.99)$ & $9 \cdot 16(5 \cdot 81)$ & $9.23(6.31)$ \\
Mothers & $7.50(4.41)$ & $6.56(5 \cdot 39)$ & $6.19(5 \cdot 59)$ \\
t & 0.61 & 1.49 & 1.73 \\
2-tail & 0.55 & 0.14 & 0.09 \\
\hline probability & 0.53 & & \\
\hline
\end{tabular}

after injury there are no statistically significant differences (independent sample $t$ test, 2 tailed).

4 What features of the patient are predictive of their relatives' psychiatric and social functioning?

This question was addressed firstly by computing correlations between measures of severity of the patients' injury and outcome, with relatives' psychosocial functioning. The correlation procedure revealed that measures of the severity of injury (PTA, coma duration) were rarely significantly associated with the relative outcome variables. But measures of patient outcome were frequently significantly associated with the relative's outcome. The level of subjective complaints in the patient was the most frequent significant correlate, especially at 6 and 12 months.

Linear regression was then used to assess whether any of the patient measures could be used to predict the relatives' psychiatric and social functioning. The dependent variables consisted of the GHQ, Leeds, global social functioning and perceived burden scores of the relatives. The independent variables were measures of the severity of the patient's injury (PTA, GCS) or its outcome in the different spheres assessed (subjective complaints, physical signs, occupational functioning, cognitive functioning, functioning in activities of daily living and personality change since injury). The independent variables were entered stepwise into the equation only if they were significantly associated $(p<0.05)$ with a dependent variable, variables with the most statistically significant associations being entered first.

No measures of severity of injury were entered into the regression equation. The level of subjective complaints voiced by patients emerged as being most predictive of the relatives' psychosocial functioning, often accounting for more than $50 \%$ of the variance.

\section{Discussion}

The relatives of head injured patients in this study 
were found to have significant psychiatric difficulties throughout the year following injury, a finding in accord with the current literature. ${ }^{6711}$ Well over $30 \%$ of relatives have levels of anxiety likely to be of clinical significance. At 3 and 6 months after the injury as many as $40 \%$ of the relatives have a high probability of having psychiatric illness. ${ }^{14}$ The relatives showed twice the level of psychiatric dysfunction found in the general population. ${ }^{8}$ Unlike most emotional disorder in the community, the relatives show persistent malfunctioning, perhaps suggestive that the provocative stress is continuing.

The relatives' social functioning is initially good, but problems begin to develop after 3 months following the injury. These remain over the rest of the year. Marital functioning in particular deteriorated significantly after the 3 month assessment but there were trends of poorer role functioning in all roles when compared with the US community norms. ${ }^{13}$ Unfortunately there are no studies with which to compare the social adjustment data.

The relatives do not consider the patients to be improving and therefore perceive for themselves a high level of burden throughout the year. This is perhaps a confirmation that the relatives' psychiatric and social distress is associated with the patients' continuing dysfunction.

Panting and Merry ${ }^{15}$ and Thomsen ${ }^{16}$ suggest that mothers of the brain injured are able to cope with the burden of caring for their relative better than wives of the brain injured. The results in this study were of a similar pattern of psychiatric and social dysfunctioning in both groups of relatives and the degree of dysfunctioning did not differ significantly in either the wives or the mothers of the head injured.

Severe head injury survivors often return home to begin a long course of recuperation. The outcome is not at all certain. Physical deficits may resolve within the first few months. ${ }^{17}$ Cognitive $^{2}$ and social deficits ${ }^{18}$ are slower to respond. Relatives are frequently unaware of these factors and not uncommonly complain of a lack of information about prognosis and outcome. ${ }^{15}$

This study supports the hypothesis that it is the patients' functioning at the time of assessment, which is critical for the relatives' wellbeing. The relatives seem to be reacting, as might be expected, to the day-to-day problems in living with the patients. The most important predictor of the relatives' psychiatric and social functioning was, in fact, the level of subjective complaints which the patients voiced.

The relatives' burden is not predicted by the severity of the injury in those who have suffered a severe head injury. It is therefore not possible to predict during admission which relatives are likely to experience greatest psychiatric and social dysfunctioning. This would only be possible at subsequent follow-up. Some workable rehabilitation scheme for all severe head injury survivors and their families which includes the capacity to deal with social and emotional difficulties is required.

\section{References}

1 Jennett B, Teasdale GM, Galbraith S, et al. Severe head injury in 3 countries. J Neurol Neurosurg Psychiatry 1977; 40:291-8.

${ }^{2}$ Brooks DN, Aughton ME. Cognitive recovery during the first year after severe head injury. Int J Rehab Med 1979;1:166-72.

${ }^{3}$ Jennett B, Snoek J, Bond MR, et al. Disability after severe head injury. Observations on the use of the G.O.S. J Neurol Neurosurg Psychiatry 1981;44:28593.

${ }^{4}$ Lishman WA. The Psychiatric sequelae of head injury: a review. Psychol Med 1973;3:304-18.

${ }^{5}$ Oddy M, Humphrey M, Uttley D. Subjective impairment and social recovery after closed head injury. $J$ Neurol Neurosurg Psychiatry 1978;41:611-6.

- Rosenbaum M, Najenson T. Changes in life patterns and symptoms of low mood as reported by wives of severely brain injured soldiers. J Consult Clin Psycho 1976;44(6):881-5.

' Oddy M, Humphrey M, Uttley D. Stresses upon the relatives of head injured patients. $B r J$ Psychiatrof 1978;133:507-13.

${ }^{8}$ Finlay-Jones RA, Burvill PW. The prevalence of minos psychiatric morbidity in the community. Psychol Med 1977;7:474-89.

${ }^{9}$ Russell WR. Cerebral involvement in head injury - a study based on the examination of 200 cases. Brain 1932;55:549-613.

${ }^{10}$ McKinlay WW, Brooks DN, Bond MR, et al. The short term outcome of severe blunt head injury as reported by relatives of the injured persons. J Neurol Neurosurg Psychiatry 1981;44:527-33.

"Brooks DN, McKinlay WW. Personality and behavioural changes after severe blunt head injury - a relative's view. J Neurol Neurosurg Psychiatry 1983;46:336-44.

12 Livingston MG, Brooks DN, Bond MR. Three months after severe head injury: psychiatric and social impact on relatives. J Neurol Neurosurg Psychiatry 1985; 48:870-5.

${ }^{13}$ Weissman MM, Prusoff BA, Thompson WD, et al. Social adjustment by self-report in a community sample and in psychiatric outpatients. J Nerv Men Dis 1978;165:317-26.

${ }^{14}$ Goldberg D. Manual of the General Health Questionnaire. Windsor: NFER Publishing Company, 1978.

is Panting A, Merry P. The long term rehabilitation of severe head injuries with particular reference to the need for social and medical support for the relatives family. Rehabilitation (Bonn) 1972;38:33-7. 
${ }^{16}$ Thomson IV. The patient with severe head injury and his family. Scand J Rehab Med 1974;6(4):180-3.

${ }^{17}$ Bond MR. Stages of recovery from severe head injury with special reference to late outcome. Int J Rehab
Med 1979;1:155-9.

${ }^{18}$ Oddy M, Humphrey M. Social recovery during the year following severe head injury. J Neurol Neurosurg Psychiatry 1980;43:798-802. 